\title{
Humour and satire in everyday life of Soviet society in the 1920s
}

\author{
Galina N. Ryabova \\ Penza State University, Russia \\ ryabogalina@yandex.ru
}

\begin{abstract}
In the Soviet society of the 1920s, humour and satire had existed at two levels: official and unofficial, each having rather diverse forms. At the official level, there were, first of all, satirical articles, humoresques, and cartoons published in the magazines and newspapers, and the latter being an integral part of Soviet everyday life. Secondly, there were performances of propaganda teams (the Blue Blouse in particular). These performances took place at any venues: in working clubs and village halls, on the factory floors, and in different offices. The repertoire of propaganda teams always included satirical couplets directed against "internal and external enemies". At the unofficial level, there were witty-ditties, funny couplets, and anecdotes. At each level, humour and satire had their own goals and fulfilled various functions: from ideological to relaxational. However, the ideological function was most clearly manifested at the official level. Humour and satire were an integral part of political propaganda. This article sets out to consider various forms of humour and satire at the official level.
\end{abstract}

Keywords: humour, satire, Soviet everyday life.

\section{Introduction}

The first decade after the Revolution of 1917 is considered to be a specific period in Soviet history. This was a transitional period when the totalitarian state had not been established yet, but old traditions and habits were still maintained along with new phenomena in many spheres of life.

In Russian science, there are many studies devoted to the existence of humour and satire in various transitional eras, but the period of the first decades of Soviet power is insufficiently studied. Meanwhile, the manifestations of humour and satire were diverse in form at this time, and laughter performed various functions to be discussed further.

Note, humour and satire are categories of comic genres. At the same time, satire is defined as "a way of manifestation of the comic in art: it is a destructive ridicule of phenomena that seem vicious to the author" (Terra-Lexicon 1998: 508). Having arisen in the folk culture of laughter, satire penetrated into theatre and literature, journalism and fine arts, and later to stage, cinema, and television. But humour is viewed as "a special kind of the comic, combining 
mockery and sympathy, an external comic interpretation, and an inner involvement in what seems funny" (Terra-Lexicon 1998: 660). Based on this understanding of humour and satire, let us consider the features of their manifestation in Soviet society in the 1920s, being a difficult stage in the history of Russia.

The collapse of previous ties, the fall of old idols and authorities, the conscious or forced violation of social norms, chaos, widespread disorder in the mode of life are the features of the everyday life of Soviet society during this transitional period. In the fair opinion of the Russian Professor Khrenov, the transitional era provokes an explosion of the comic (Khrenov 2002: 327). The reason for such an explosion is a change in the social order and the social hierarchy. The social ladder turns over and those who have risen from lower social levels to the top begin to ridicule those who are at the bottom (Khrenov 2002: 325). There have been several transitional eras in the history of Russia, and the twenties of the 20th century were one of less studied ones.

The purpose of this study is to determine the place and role of humour and satire in the everyday life of Soviet society in the 1920s. To do this, it is necessary to highlight the forms, content, and functions of humour's and satire's existence in everyday life.

A distinctive feature of this historical period was the active use of humour and satire by the authorities to achieve their goals. This was a novel phenomenon to Russian reality. A contemporary Ukrainian researcher Stolyar raised the question of the relationship between ideology and the culture of laughter. She also expressed the idea of the dynamics of the culture of laughter and the need to determine its dominant forms at a particular stage (Stolyar 2011: 89).

A British sociologist Christie Davies (2014) wrote about the specificity of humour in socialist countries, primarily in the USSR. He identified three types of political humour practiced in these countries: cruel political humour of the elite; humour in the form of caricatures and posters created by the intellectuals; and spontaneous mockeries and anecdotes that existed among the people. This point of view can be admitted as one of the approaches for the study of humour and satire in the USSR. However, in our opinion, there were far more forms and expressions of humour and satire in Soviet society.

There were two levels of humour and satire (official and unofficial) which existed in the first decade of Soviet power, but their forms were rather diverse. At the official level, they were represented, firstly, by the printed word and caricatures published in the press. Secondly, these were the performances of various agitprop theatres, and Sinyaya Bluza (Blue Blouse) being the most famous one. At the unofficial level, humour and satire were expressed in anecdotes, chastushkas (ditties), and various forms of folklore inherited from traditional culture. This article is supposed to consider the manifestation of humour and satire at the official level.

\section{Satire and humour magazines}

Reading newspapers and magazines was part of the daily life of a Soviet citizen. According to Lebina, a researcher of Soviet everyday life, young people spent about an hour and a half on self-education and self-development, "that is, on reading books and newspapers, classes at clubs and schools, visiting lectures and exhibitions" in the early 1920s (Lebina 2015: 273). Reading newspapers was an obligation for concerned Soviet citizens. The 11th Congress of the Russian Communist Party (bolshevik) (RCP(b), held in the spring of 1922, obliged every communist to become a reader and a subscriber to one of the party newspapers (The Communist Party of the Soviet Union in Resolutions and Decisions of Congresses, Conferences and Plenums of the Central Committee (1898-1988) 1983: 524). This obligation for the members of the Communist Party of the Soviet Union (CPSU) was maintained until the demise of the CPSU. 
The implementation of this requirement gave rise both to publication of a large number of various newspapers and magazines, development of a library network, and creation of clubs and village reading rooms in the countryside. It is necessary to pay attention to the fact that village reading rooms had existed in pre-revolutionary Russia. However, at that time, they were initiated by zemstva (local self-government bodies), and were really educational in nature. But it was already in the first years of Soviet power when the nature of their activities began changing. Village reading rooms turned to be a part of the state propaganda plan. It was in order to achieve the goals set by the state that they received a variety of both local and national newspapers and magazines in large quantities. It is easy to find this fact in a typical article How our club works, published in the weekly illustrated magazine Pod Znamenem Leninizma (Under the Banner of Leninism) issued in the Penza province. Talking about the reading room at the Narovchat party and professional club, a press correspondent meticulously listed the names and quantities of newspapers and magazines supplied to the club. He also reported on the amount of money spent on subscription (15-18 roubles monthly), and gave information on the reading room attendance (about 50 persons per day) (Pod Znamenem Leninizma 1926. 26: 34). If we take into account the fact that the monthly subscription fee for this magazine was only 25 kopecks for institutions, and it was 55 kopecks for the magazine Krokodil (Crocodile), then we can imagine how many newspapers and magazines this reading room had received. Note that the Penza province, located in the centre of Russia and being a part of the Volga region, is a typical province. Many phenomena of everyday life in the 1920s, which took place in the Penza province, were typical for other provinces of Russia.

The party leadership paid close attention to the affairs of the press. Back in 1919, a special decree 'On the party and Soviet press' was adopted at the 8th Congress of the RCP(b). It stated that "the press is a powerful instrument of propaganda, agitation and organization, an irreplaceable means of influencing the broadest masses" (The Communist Party of the Soviet Union in Resolutions and Decisions of Congresses, Conferences and Plenums of the Central Committee (1898-1988) 1983: 116). According to this resolution, the press was set a target to disclose various crimes of officials, to point out faults and problems in the work of Soviet and party organizations. The question about the press and propaganda was placed at the 11th Congress of the RCP(b) (The Communist Party of the Soviet Union in Resolutions and Decisions of Congresses, Conferences and Plenums of the Central Committee (1898-1988) 1983: 525526). And in 1927, the Press Department of the Central Committee of the All-Union Communist Party (Bolsheviks) adopted a resolution directly related to satire and humour magazines.

Almost all periodicals published in those years in the USSR contained satirical or humorous materials. For example, there were cartoons of famous world politicians or an important event placed on the pages of newspapers and magazines. Feuilletons and political pamphlets, humoresques and parodies, ditties and epigrams appeared periodically. Each issue of the newspaper Pravda (Truth) contained satirical works by Demyan Bedny and other satirists (Stykalin \& Kremenskaya 1963). Besides, special satire and humour periodicals were published.

So, in the summer of 1922, the magazine Krokodil was issued. It was initiated by Konstantin Eremeev, an ex-sailor of the Baltic fleet and a professional revolutionary (Pyanov 2007: 23-24). This magazine became popular and gained a large readership all over the country. Moreover, the word 'krokodil' was present in numerous publications. For example, there were such magazines as Voenniy Krokodil (Military Crocodile), Krokodil Luganskiy (Crocodile of Luhansk), Krokodil v Zapadnoy Ukraine (The Crocodile in the Western Ukraine), Bezbozhniy Krokodil (Faithless Crocodile), etc. Pyanov, the former editor of Krokodil and a famous satirical poet, wrote that "according to reliable sources, 240 satire and humour publications appeared in the country after the issue of Krokodil" (Pyanov 2007: 26). The circulation is also an evidence of the magazine's popularity. In 1923, the circulation of Krokodil was 150,000 copies; in 1927, it grew up to 175,000 copies. Note that, at first, Krokodil was given to all subscribers of 
Rabochaya Gazeta (The Workers' Newspaper) free of charge, which also determined the popularity of this magazine (Stykalin \& Kremenskaya 1963).

Numerous humour and satire magazines addressed a wide variety of population speak volumes. Firstly, it concerns the popularity of publications of this kind among the readers. Secondly, there was a burst of cultural creativity among various segments of the population, which manifested itself in diverse forms, including the publication of newspapers and magazines. Poets and artists were among the publishers and founders of satire magazines. Creative intellectuals, who were characterized by revolutionary romanticism, perceived the revolution as a thunderstorm, washing away the dirt and dust of the old world. Poets and artists were sure that, having destroyed the old foundations, they would create a new, more perfect world. Accordingly, those who somehow personified these foundations were perceived as enemies of the new life. It meant that, according to the conviction of the revolutionary-minded creative intellectuals, it was necessary to fight against them. For example, the credo of the magazine Smekhach (Comedian), being published in Moscow and Leningrad from 1924 until 1928, was expressed as follows:

We are merciless in our fight.

Our mortars will keep on rumbling!

Each of our enemies

Will taste

The cannonballs of our satire.

We'll fill hundreds of gaps.

There is no protective armour,

If the bayonet is irony,

And if the squadron is satire.

(Stykalin \& Kremenskaya 1963)

The poets Mikhail Koltsov and Vladimir Mayakovsky, the artists Mikhail Cheremnykh and Ivan Malyutin, etc. were mentioned among the founders of the magazine Smekhach. Finally, the authorities did not prevent the publication of such magazines, but encouraged it until 1927. Despite the fact that the Main Directorate for Literary and Publishing Affairs, known as Glavlit, was created in 1922 to carry out censorship, there was no ideological rigidity, and the content of magazines was sometimes far from party tasks.

In this regard, the magazines were criticized in the decree of the Press Department of the Central Committee of the All-Union Communist Party (Bolsheviks) of 14 May 1927, and a turn was outlined in the satirical and humorous press. The document testified to the end of diversity and a certain freedom. It noted that though seven magazines had the largest total circulation (half a million copies), which indicated their popularity among readers, they did not perform well. Apparently, this popularity alerted the authorities, who decided to put humour and satire under their control. The decree pointed out the need to differentiate magazines by reader groups, that is, each magazine should have its own readership. Krokodil and Begemot (Hippopotamus) were supposed to focus on politically mature workers, Buzoter (Brawler) - on the members of trade unions (i.e., on workers), Smekhach - on employees, and Lapot' (Bast Shoe) - on the peasantry (Happiness of Literature 1997: 59).

A year later, a new resolution On satirical journals of the Secretariat of the Central Committee of the All-Union Communist Party (Bolsheviks) was issued, which put the satirical and humorous press under more rigid control of the party, being expressed in demands to replace editors and purge the editorial staff. In addition, Sergey Ingulov, the Head of the Agitation, Propaganda and Press Department, was instructed to conduct briefings among editors regularly, at least once every two months. Other repressive measures included closures of the magazines Begemot and Bich (Whip) (Happiness of Literature 1997: 59-60). 
The same fate befell the satirical press in the provinces, where many magazines were published in the first half of the 1920s. But we can say that provincial satire had not had time to strengthen its position yet, the release of satirical newspapers and magazines was not stable, and sometimes only a few issues were published. Initially, the reason for such a short existence of publications was a lack of funds for the publication of newspapers and magazines, and a lack of qualified personnel.

The rapid development of the satirical press in the first half of the 1920s benefited from the experience of the pre-revolution period. The magazine Satirikon, published from 1908 until 1914, was one of the most famous pre-revolutionary satire magazines. Moreover, a modern writer Igor Klekh believes that Satirikon "set a kind of standards of the urban culture of laughter: from Sasha Cherny and Mayakovsky - through the leading figures of Soviet laughter (including the laughter of Krokodil and Literaturnaya Gazeta (The Literary Newspaper) - until the modern comic television culture..." (Klekh 2013). In other words, famous writers and artists created a kind of model for later generations to rely on.

A distinctive feature of pre-revolutionary publications was the fact they were edited with private money, and in this regard, they were not supported by the government. That is why it is impossible to say that satirical publications expressed the official point of view of the authorities. On the contrary, state censorship often hindered their activities.

After the 1917 Revolution, the situation became completely different. The Soviet government supported and, at the same time, controlled the edition of humour and satire magazines, since it regarded humour and satire to be effective means for establishing a new ideology and fighting its ideological opponents. The periodicals in general, and satirical press in particular, reflected all internal and foreign political events through the prism of Bolshevik ideology. A class approach was applied when considering any phenomenon, including laughter. Thus, having applied this approach, the People's Commissar of Education, Lunacharsky, built his concept of laughter. Speaking about class laughter, he noted, "In the class society, laughter is differentiated: it can be reconciling and it can be fighting, cruel" (Gak \& Glagoleva 1965: 195).

The Soviet People's Commissar was familiar with Henri Bergson's concept of laughter. Having analysed the ideas of the French philosopher, Lunacharsky paid special attention to laughter at the stranger. The People's Commissar concluded that laughing at a stranger contributes to the consolidation of the group, and that there is national humour and laughter, as well as class laughter. We can accept that, from the point of view of any group, the manners and the acts of the representatives of another group might look ridiculous. Social groups might be an example of this phenomenon. But Lunacharsky confirmed the absolute nature of such a division. Furthermore, he believed that the laughter of lower classes had more complicated aspects than the laughter of upper classes. The upper classes laughed at the lower classes so as not to become like them (Gak \& Glagoleva 1965: 195). This position seems to be simplified and unfounded. Such outstanding satirical writers of the 19th century as Nikolay Gogol, Aleksandr Ostrovsky, and Mikhail Saltykov-Shchedrin were not the representatives of lower classes. Their laughter was not directed top-down or bottom-up. They criticized human vices and social order equally. At the same time, the folk laughter culture had its roots in pagan times and it was often associated with an agrarian calendar and folk fests. Therefore, the class approach to the culture of laughter, as well as to culture in general, can be considered as prejudicial, as it determined its one-sided development at the official level. At the same time, it stimulated the development of unofficial laughter.

Lunacharsky distinguished between two forms of laughter, namely, humour and satire. In his opinion, in everyday life, there should be amiable humour, which would be applicable to individual shortcomings in the group of associates. As for satire, Lunacharsky had an opposite approach. He wrote that "obviously, if the object of mockery is regeneration, there is no place 
for amiability. And the more this phenomenon is odious and dangerous, the more biting the humour is, the more it becomes satire" (Gak \& Glagoleva 1965: 199). Besides, Lunacharsky had made a scale of laughter: evil laughter, laughter through tears, festive laughter, and triumphant laughter. Since the People's Commissar of Education controlled both the education sector and culture, including book publishing, he set a special mission for satirists and humourists. Lunacharsky claimed to use the most biting satire towards the external enemies, like the upper classes, bourgeoisie, and social democrats. Satire should help to explode and break the reputation of these classes in the eyes of the working class and even destroy selfidentity of the members of deposed classes (Gak \& Glagoleva 1965: 200).

Humiliation was one of the techniques that Lunacharsky recommended for use. Laughter was supposed to humiliate and cause bitter feelings. Lunacharsky concluded that "to attack a human being by laughter is a very reasonable instrument" (Gak \& Glagoleva 1965: 195). This humiliation was to be found in all types of satire. All these theoretical considerations and practical recommendations of the party leadership were actively implemented in everyday life. They were reflected both in cruel and mocking humour of the political elite, which became widespread already in the 1930s (Davies 2014), and in the satirical works of professional poets, writers, artists, and journalists.

Thus, the satirical press occupied a prominent place in the daily life of Soviet society in the 1920 s, as evidenced by variety and circulation of published magazines. However, two stages can be conditionally distinguished in the development of satirical press in the 1920s, the year of 1927 being the boundary. At the first stage, a lot of satire and humour magazines were published. Some of them were oriented to specific social groups. They were both available to the general reader through the system of libraries and reading rooms, and were also popular.

The publishing of magazines was sometimes initiated by writers and artists who relied on pre-revolutionary experience. From the very beginning, the party leadership had set the goals and objectives for Soviet satire and considered laughter as a tool of propaganda and agitation. But there was no strong pressure in the first half of the 1920s.

\subsection{Satire genres in journalism}

Humour and satire were represented by various genres in Soviet periodicals of the 1920s: feuilletons, parodies, epigrams, poems, ditties, and anecdotes. A distinctive feature of satire in any historical era is its topicality. It always refers to the events and phenomena of our time, which determines the theme of satirical works. However, the choice of a specific event or a phenomenon being an object of satirical ridicule, can be influenced by the socio-cultural situation, which determines the norms and deviations; by personal beliefs and attitudes of the author of the satirical work; or by the interests of the social group (political party) represented by the satirist. In the USSR, the state ideology was an important factor that influenced satire throughout Soviet history.

A feuilleton was the most widespread genre of satirical press during the period under review. In satire magazines, feuilletons occupied a leading place. During the period of the New Economic Policy (NEP), the NEPmen (private entrepreneurs) and intellectuals (primarily, scholars in the humanities) were the main objects of ridicules in the feuilletons of the 1920s.

Having analysed the nature and the tone of satirical publications, we can conclude that the NEP had been initially doomed. The lexis used for describing the NEP was quite negative, forming an unpleasant image of the NEPmen and a rejection of the NEP, e.g., "mud and rot of the NEP", "an ugly face of the NEP", "a fat-bottomed sovbur (Soviet bourgeois)", "a largemuzzled NEPman", etc. The magazine Krokodil had a regular section that represented a kind of comic encyclopedia which contained humorous and satirical definitions of new and actual notions. For example, the word 'NEPman' was explained as follows: "The NEPman's 
appearance has no difference with the bourgeois. But according to Brehm's Life of Animals, the NEPman is a tamed bourgeois, and he does not occur in a wild capitalist status on the territory of the USSR" (Krokodil 1923. 2: 515). The NEPmen were characterized only from the negative side as wasters or bloodsuckers, who bid up prices for their articles.

It has been mentioned that the intellectuals and scientists, along with the NEPmen, were subjected to ridicule. For example, in the feuilleton 'On the living pogost (churchyard)' by Gramen (a literary pseudonym of Nikolay Ivanov-Gramen), a priest, a professor, an engineer, a lawyer, a merchant, and a writer are described as living corpses. A sexton, named Pafnuty, gives them an order, "Do not stink above the norm!" (Krokodil 1922. 1 (13): 5). In many works, there was a negative attitude towards scientists. The reaction of Krokodil to the expulsion abroad of humanitarians, compared with a herd by Gramen, is demonstrative.

The attitude of the new government to the old specialists, especially the intellectuals, was contradictory. On the one hand, they tried to win them over to the side of the Soviet regime and, on the other, they were treated with distrust. Some of them got privileges and honours, good conditions of work, and special allowances from the state. In 1921, under the Soviet government, TsEKUBU (Central Commission to Improve Living Conditions of Scientists) was founded to create conditions for the work of scientists. Other scientists were ranked among the enemies of Soviet power, even if they showed a tolerant attitude towards the Soviet authorities. Among the opponents were the scientists specializing in humanities, who were considered unnecessary and even adverse. The following piece of poetry demonstrates this attitude:

Thirty-six professors

They are going abroad.

They are going through the field,

Droning on, and on, and on...

They are going against their will.

They look glum without allowances from TsEKUBU!

(Krokodil 1922. 2 (14): 4)

It's not difficult to understand how such materials resonated with the mind and the soul of under-educated people. Malicious joy was the only reaction.

Another feuilleton by Gramen From the Russian life (A story of the daily life) represented the caricature of a Soviet scientist. The author wrote that "there were pleasant, highly cultured thoughts and images fluttering in the professor's head". This characteristic was used to show the shallowness, lack of seriousness, and low social value of the scientist. The professor's thoughts were seditious from the point of view of the new government. The author of the article associated culture and art with the NEP. This was a direct distortion of facts, with the help of which the negative attitude towards the NEP was transferred to the intellectuals. The name of the leader of the Constitutional Democratic Party, a historian Pavel Milyukov, was used as a connection between the intellectuals and counter-revolution. Based on this, the reader could draw a conclusion about the counter-revolutionary attitude of scientists. In addition, the feuilleton demonstrated the negative attitude of the authorities towards culture and art. Art was perceived as something secondary and unimportant.

By mistake, the professor took the pork for the NEPman and was discussing the development prospects of Russia with it. The professor said, "The recipe of success is in a close collaboration between the new bourgeoisie and us, people of science culture!" Thus, the idea that the intellectuals were at one with the NEPmen (the new bourgeoisie was also mentioned) and counter-revolution should have been imprinted in the mind of the readers. The final of the story should persuade the readers about it because the professor wrote a letter to Paris and reported that "(...) Unfortunately the machinery of dictatorship is still powerful. Our efforts to 
consolidate with the most cultural layer of the bourgeoisie are nipped in the bud" (Krokodil 1922. 2 (14): 6).

Corruption, bribery, excessive bureaucracy, and alcoholism were the major problems of the new regime. These topics were castigated in almost every issue of central and provincial press. An interesting caricature Vzyatka (Bribe) by an unknown artist was published in the first issue of the magazine Tovarishch (Comrade) in 1922 (see Figure 1). This caricature demonstrates a character without legs, but with six arms, and his head consisting of hands (Tovarishch 1922. 1: 2).

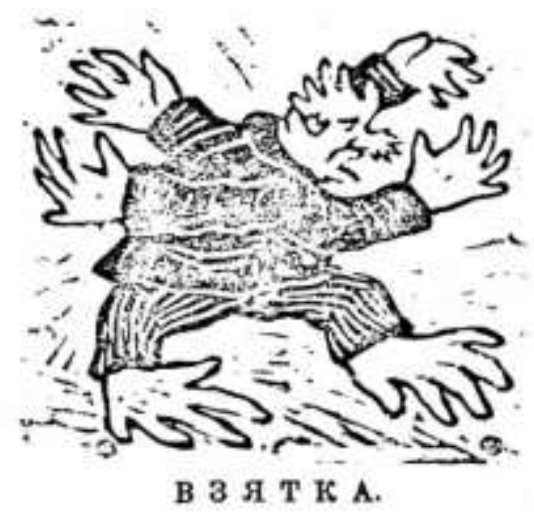

Figure 1. Vzyatka (Bribe). Unknown authorship. Source: Tovarishch 1922. 1: 2

In the same issue of the magazine, there is a story At the railway station devoted to bribery that can be considered as an anecdote:

"Citizens, observe the line! Stay at the end of the line! Hey, man, why did you skip the line? Others may have been waiting since morning! ..."

"But the train will leave now! I can't go without a ticket..."

"Here is the ticket office! ... And here is a window for bribes. What's wrong with people! One can't get used to order! ..."

(Tovarishch 1922. 1: 6)

Alcoholism and bootlegging of samogon (home-distilled vodka) were sharply ridiculed in central and provincial satire magazines. For example, a feuilleton-parody Our industry. The report of vodka brewer was published in the first issue of the magazine Tovarishch in 1922 (Tovarishch 1922. 1: 2-3). The poem Picnic, which denounced the practice of corporate drunkenness of the workers of enterprises, was published in the thirteenth issue of the magazine in 1923. It was accompanied by a caricature (Tovarishch 1923. 13: 7).

The feuilletons Fight with samogon and Shtof bogatyr (a bottle named 'hero') published in the eighteenth issue of Krokodil in 1922 told about the unsuccessful fight with bootlegging of samogon (Krokodil 1922. 18: 488).

The situation of alcoholism and bootlegging of samogon was a tight spot, and all efforts to resolve it had been failing during several years running. Moreover, the representatives of the new government gave a bad example. Alcoholism was widely spread among the young Komsomol (The All-Union Leninist Young Communist League) members and the members of the Party. A modern writer and researcher Igor Orlov writes that "there is a reason why people called a bottle of 0.11 as 'a pioneer', a bottle of 0.21 as 'a komsomol member', and the bottle of 0.51 as 'a partiyets' (a member of the party) with high respect"' (Orlov 2010: 251). 
A lot of attention was paid to the home life of Soviet citizens on the pages of Krokodil. The magazine showed the attitude of the Bolsheviks towards this problem. The home life contrasted with the values of the revolution and remained changeless. The idea of active participation in public life and revolutionary transformations was brought to the fore. The attempts of people to come back to an ordinary life, in the name of which the revolution had been accomplished, were considered as bourgeoisie and were satirized. There could not be an individual person, but there was a participative member of the society. A satirical work The mud of home life by Kubansky (a literary pseudonym of Evgeny Pyatkin) was published in the first issue of Krokodil in 1922 (Krokodil 1922. 1: 6-7). Itis necessary to point out that satire of the 1920s was not ordinary. One cannot consider all the publications to be satirical. It was rather a pseudo-satire, since the task of satire is to criticize, ridicule, and scourge public vices. Soviet satire of the 1920s was directed not only against social flaws, but also sometimes against traditional values that laid the base of people's life but were rejected by the Bolsheviks at that time. Therefore, one can talk about the existence of pseudo-satire that was characterized by acuity and severity. The feuilleton 'The mud of home life' had united three short stories of life that showed how the individual was passing from the revolutionary fight to peaceful life. This process was natural and logical but it did not conform to the Bolsheviks' idea of new life. Therefore, the feuilleton condemns the quiet, peaceful life of the former Red Army soldier Pavel, which is considered moral decay. A similar transformation touched a student, Seminarsky, who having gone through prison and exile in tsarist Russia, "works again and doesn't complain”, lives his peaceful life and plays solitaire. The third story is about the place and the role of a Soviet woman in social life. Both the 'irresponsible' husband of Masha Petrova, who was against the social activities of his wife, and then Masha herself, who decided to baptize her newborn son, are condemned.

The Soviet government favoured the emancipation of women. Active participation of women in social life was welcomed. The revolution announced the liberation of women from housework. The party organizations tried to involve women in the building of socialism. These organizations gave reports in the press about the number of women admitted to the Party, elected to the leading Soviet and party bodies. A new feminine ideal was not to be a woman-mother or a housewife, or a homemaker, but a woman-social activist. Therefore, the feuilleton condemns the claims of Masha's husband and his dissatisfaction with her participation in all kinds of meetings.

The moral of the feuilleton was as follows: "Let the mud rot away. Those who can will stand up again. The mud of life doesn't frighten those who had known the fight and the blood. We are not afraid of the coldness of the crypt; drunkenness, sleepiness and gamble. Let's put a sharp red knife of laugh into an ugly face of the NEP" (Krokodil 1922. 1 (13): 7). Surprisingly, even in these stories, the author finds an opportunity to condemn the new economic policy. The NEP is accused of the fact that ordinary people began to improve their lives. This, of course, is absurd, but the author of the feuilleton did not need logic, the main thing was to once again emphasize the danger of the NEP, since even active participants in the revolution are 'reborn' under its influence.

It is interesting that a lot of magazines, including Krokodil, received feedback. From the very first issue of the magazine, there appeared a regular column Vily $v$ Bok (A Hayfork to the Side). It published excerpts from provincial newspapers, which reported shortcomings, abuse or curious cases, and letters from readers. Davies noted that citizens were encouraged to send complaints against minor officials to the central authorities and the press, and they were promised to publish them after checking the 'signal'. But the letters with complaints against hunger, cold, and scarcity had never been printed (Davies 2014: 10). Indeed, an analysis of Krokodil for the 1920s has showed that there were practically no letters published that had discussed such problems. 
Most of the publications in this column dealt with the same questions about bureaucrats, bribery, and clergy. Only occasionally did letters appear on the pages of the magazine about people's living conditions. For example, the teachers from the Chechen village of Satty complained about delayed wages and the lack of firewood at school. The editors answered, "And they say to live and learn. Under such conditions, one won't live a year, let alone a century in Satty" (Krokodil 1927. 10: 10).

The magazine's reaction to complaints was sometimes in the form of an epigram, a caricature, or a small note. Such publications had their own titles, e.g., Bow with the peasantry or Woe from wit (Krokodil 1922. 2 (14): 11). The first reported that, in the Smolensk province, a tenant conducted a survey among the peasants to find out the reasons for the poor sale of beer. The questionnaire asked, "Why don't the peasants drink beer?" The peasants replied, "Because it is not cheaper than samogon". The editorial board of the magazine reacted to this with the following epigram:

So laugh through tears here,

But mind you, honest brothers,

That it was the 'damned' question

And the answer is even more accursed.

(Krokodil 1922. 2 (14): 11)

It is interesting that complaints were received both from the provinces and from Moscow. For example, the students (future party and Soviet workers and agitators) of the Sverdlov Communist University complained about the lack of running water and toilets in the student hostel, although it was located in the very centre of Moscow. Krokodil responded with a caricature (a crocodile holds a toilet bowl with washbasins on a tray) to this complaint (Krokodil 1922. 7: 15). This fact is remarkable, as it shows a dismissive attitude towards a person.

There was another column, Stranichka Chitatelya (The Reader's Page), where satirical notes and humorous stories of the readers were published. But the answer of Krokodil to various authors about the reasons for the refusal to publish was posted most often here. The main reason for the refusal was the low level of such works.

Thus, satirical journalism was represented by different genres. The leading place among them was taken by the feuilleton. The characteristic features of satirical works were onesidedness, due to the class approach, and sharpness.

Satire of the 1920s was characterized by the monotony of themes being exaggerated and reinterpreted in each issue. The NEPmen and officials, the clergy and intellectuals were invariably presented as objects of ridicule. Soviet satire was directed not only against social vices, but also against the traditional foundations of the society.

With the help of satire, the authorities formed a negative attitude towards the NEP, sought to introduce new traditions of everyday life, and to consolidate the emerging system of values.

\subsection{Political caricature in satire and humour publications}

Caricature can be considered as one of the most operative forms of satire. It is known to be an image in which the artist deliberately creates a comic effect with different nuances: from a goodnatured joke to sharp satire. It may contain grotesque and parody. According to Krotkov, "in a truly democratic society, a caricature having a purely entertainment function, also plays a very important role as the freedom barometer" (Krotkov 2015: 58). However, under the conditions of a totalitarian society, the caricature began to serve the interests of the authorities and satire prevailing therein.

Both researchers (Davies 2014; Golubev 2018; Krotkov 2015) and caricaturists (Efimov 2000) wrote about the significance of visual images and the power of their effect on the 
audience. Davis attributed caricature to the second level of ridicule and humour under socialism. The author believed that well-paid writers and caricaturists, deprived of creative freedom, were the creators of ridicule at this level (Davies 2014: 8). We consider this statement partly inexact. Indeed, there were representatives among the intellectuals that were promoted by the authorities, e.g., a poet Bedny, an artist Efimov, etc. On the one hand, without any doubts, they fulfilled the orders of the government. On the other hand, the artists usually shared the point of view of the government, that is, it was largely their own position. For example, the poet Mayakovsky that had acclaimed the Revolution of 1917 considered his art as a service to the highest purpose of the establishment of the new society. It is no coincidence that the poet ridiculed everything that, in his opinion, hindered the achievement of these goals. While working for the ROSTA Windows (ROSTA is an acronym for the Russian Telegraph Agency), satirical posters by Mayakovsky were characterized by a pronounced revolutionary expression. And such poets and artists were in abundance.

Furthermore, as noted earlier, a certain proportion of freedom existed in the 1920s, especially during the first five years of the decade. As for provincial writers and caricaturists, their works were hardly well paid. In the meantime, the caricature was widespread and was in demand. A contemporary Russian researcher Golubev notes that the audience appreciated and was looking forward to the caricatures. He wrote, "There were cases when the audience was so numerous in front of the newspaper stands with the caricatures that they disrupted the traffic in the centre of Moscow" (Golubev 2018: 89-90). The popularity of caricatures is also evidenced by the following fact. In February 1927, the editorial board of the magazine Krokodil announced a caricature competition in which both professional artists and people's correspondents (amateur proletarian journalists) could take part. The artists who worked for the magazine on a permanent basis were not allowed to participate in the competition. Strengthening of ties with readers, development of interest in caricature, and stimulation of artistic creativity of the masses were the goals of the competition (Krokodil 1927. 8: 2). The competition received a lively response and over 150 works of readers were published in the magazine from February to the end of December. But these were the best works, so the total number of participants was much higher. The geographical scope of the participants indicated both the distribution of the magazine and its popularity among readers, and the passion for caricature. The works marked by the jury were sent from thirty-seven cities, from Kiev to Tomsk, and from Arkhangelsk to Odessa.

The researchers of the genre of the Soviet political caricature note its harshness, apparent rudeness, and "readiness for a personal attack against prominent politicians of different political orientation from all over the world - from Hoover to Gandhi, and from Goebbels to Gompers" (Golubev 2013: 239). Davies gave an even harsher assessment to the Soviet caricature, noting its viciousness. He opposed the Soviet caricatures to the ones of the Western democracies, acknowledging the lack of delicacy in the Soviet caricatures. He also noted that the Soviet caricatures usually mocked the physical features of political leaders (Davies 2014: 9).

However, in the 1920s, these features had not been fully manifested and the internal enemies' had not been personified yet. The struggle for power within the party and state apparatus had not reached its apogee. Therefore, a generalized character of the NEPman or the clergy, as 'internal enemies', was most often encountered in the caricatures in the period under consideration. As for the personalities, there were a lot of caricatures of representatives of political parties of pre-revolutionary Russia on the pages of the Krokodil magazine in 19221923, e.g., the leader of the Socialist Revolutionary Party Viktor Chernov, the leader of the Menshevik Party Yuliy Martov, and the leader of the Cadet Party Pavel Milyukov. All these politicians had already emigrated from the country by that time, and Martov was seriously ill. It is difficult to imagine that they were a real threat to the Soviet state at that moment. But these politicians personified parties whose programs opposed the program of the Bolsheviks, and they 
had their supporters in the USSR. Therefore, the caricatures of the leaders of political parties were intended to discredit their ideas. A caricature of Martov by Dmitry Moor (a pseudonym of Dmitry Orlov), published in Krokodil in January 1923, was a vivid illustration of this fact. The leader of the Mensheviks was depicted as a parrot repeating, "The surest path of Russia's development is the path of capitalism" (Krokodil 1923. 3: 540).

Both Russian and European politicians, especially Prime Minister of France Raymond Poincaré and British Prime Minister David Lloyd George, often became the object of caricatures during this period. For example, there were caricatures of Poincaré in seven of the eighteen issues of the magazine Krokodil for 1922, and there were fourteen caricatures in the issues for 1923. The total number of issues for 1923 being forty-eight, this is approximately one third of all issues for two years. Moreover, there were two caricatures of the French Prime Minister by Moor and Malyutin in the second issue of the magazine Krokodil for 1922 (Krokodil 1922. 2: 8-9, 13). Moor's caricature Teatr Krokodila (The Crocodile Theater) was divided into three parts. In the first part, Raymond Poincaré was brought out as a participant in the performance among other politicians. In the third part, he was dancing with David Lloyd George to the sounds of the workers' International, as the caption under the cartoon reported. In fact, the caricature Bliznetsy (The Twins) by Malyutin is a parody of Poincaré, presented as a pitiful imitation of Napoleon. The attention of Soviet caricaturists to the mentioned leaders was not accidental and it was explained by their effect on European politics.

The name of Raymond Poincaré has long been associated with war in mass consciousness. This is largely why the Ruhr crisis of 1923, in which the French Prime Minister played an important role, immediately attracted the attention of Soviet caricaturists. The crisis was the subject of caricatures and feuilletons in thirteen issues of Krokodil for 1923. There were several caricatures of the Ruhr crisis in some issues of the magazine. For example, there were two caricatures in the tenth issue of the magazine Krokodil, namely, a caricature Druzheskaya Sdelka (Friendly Deal) by Ivan Malyutin and a caricature Angliyskiy Appetit (English Appetite) by Mikhail Cheremnykh (Krokodil 1923. 10: 641, 645). This topic was continued by the provincial press, as evidenced by the magazine Tovarishch, published in the Penza province. There were two caricatures by unknown authors devoted to this topic in the fourth issue of the magazine, namely, Maslenitsa in Western Europe (Blini of the Ruhr) and R-uh-rrr (Tovarishch 1923. 4: 2$3)$.

The name of the first caricature was associated with the Russian folk fest Maslenitsa (Crepes Week) and traditional dish 'blini' (crepes). The second caricature is rude. France is represented in the form of a French bulldog, Germany is depicted as a German shepherd dog, Belgium is shown as a dachshund, and the Soviet state is represented as a Red Army soldier with a truncheon in his hands (see Figure 2).

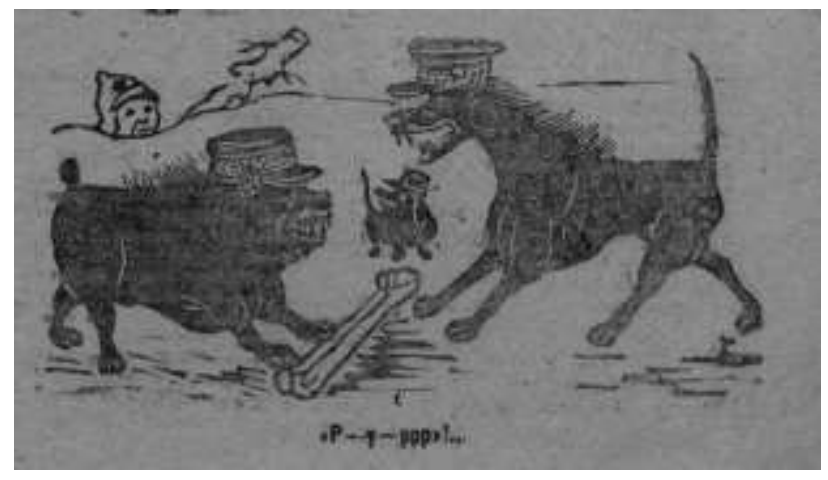

Figure 2. Unknown authorship. Source: Tovarishch 1923. 4: 3 
The semantic content of all these caricatures is approximately the same. They had to make the Soviet people think of the collusion between the bourgeoisies of different countries against their proletarians; of the idea to oppose proletarian internationalism to this conspiracy; and of the imminent war and world revolution. Based on this, the reader should have concluded that the USSR could not stand aside and would provide assistance to the European proletarians in the struggle against the bourgeoisie. Every social and political event in the West was considered as a potential source of the world revolution, and therefore, the Red Army and the Soviet people should be ready to support it.

It should be noted that the idea of a world revolution and an imminent war was firmly entrenched in the minds of the Bolshevik leaders during these years. This is evidenced by the resolution 'On the coming imperialist war' adopted at the 10th Congress of the RCP(b) in 1921. It suggested issuing a manifesto with an appeal to the workers of all countries about the war that the imperialists had been preparing for a long time, and which was about to break out (The Communist Party of the Soviet Union in Resolutions and Decisions of Congresses, Conferences and Plenums of the Central Committee (1898-1988) 1983: 375). That is, the caricatures had certainly reflected the point of view of the party leadership.

The propaganda character of the caricatures is indicated by the presence of a kind of the epigraph. Its purpose, in our opinion, was, on the one hand, to give the caricature more credibility and, on the other, to clarify the situation. The caricature itself expressed a satirical assessment of the event or the character. For example, in the above mentioned caricature Druzheskaya Sdelka, an extract from a newspaper (not specified) was placed at the top of the page on the right: "In the face of the events in the Ruhr, Germany is forced to buy coal abroad. Stinnes profits 60 thousand in gold per week". There was a caption under the caricature: "Stinnes (to Poincaré), 'As an honest German, I beg you to extend this occupation. I agree that you will take a cut' " (Krokodil 1923. 10: 641).

The artist depicted Hugo Stinnes and Raymond Poincaré sitting at the table with fruit baskets, two champagne coolers, and a bottle of wine thereon. The politicians are keeping full wine glasses in their hands, Stinnes' free hand lying on Poincaré's shoulder. In the background, there is a painting showing a naked woman in a vulgar position as a symbol of the perverseness of the bourgeoisie regime.

It is certain that such caricatures influenced the formation of a picture of the modern world in the minds of Soviet readers. In this world, the aggressive bourgeoisie of the West wants to unleash a war in order to push the proletarians of France and Germany against each other. But the interests of the bourgeoisie are alien to the proletarians, and therefore, they must unite. These ideas were also supported by feuilletons. For example, in the tenth issue of the magazine Krokodil for 1923, two feuilletons by Lazar Mitnitsky On the high road (A reparation fairytale) and Politchas (in Rurskiy not Russkiy) (An hour of political study in the Ruhr dialect, but not in the Russian language) were published.

The name of the first feuilleton was named with the reference to a Russian saying 'a bandit from the high road'. The role of bandits was played by German and French bourgeois robbing the proletarians (Krokodil 1923. 10: 642). The second feuilleton explicitly states that Poincaré is a friend of Stinnes and an enemy of the workers (Krokodil 1923. 10: 642).

In fact, there are real historical events reflected in the feuilletons and the caricatures. Under the terms of the Treaty of Versailles, Germany should supply coal from the Ruhr coal-basin in an account of reparation. Since Germany had delayed the supply of coal, France and Belgium used it as an excuse for invading the Weimar Republic. It provoked a general strike in the country. The Reich Chancellor Wilhelm Cuno appealed to citizens for 'passive resistance'. The Occupation of the Ruhr had been induced by France in order not to admit the economic recovery of Germany. A German industrialist Hugo Stinnes was the owner of the power plant in North Rhine-Westphalia. He was called 'the landlord of the Ruhr' and 'the new Emperor of Germany'. 
The policy of 'passive resistance' initiated by the German government caused damages to enterprises of the Ruhr. However, Stinnes profited from inflation and currency speculations.

Soviet caricaturists were interested in international topics from time to time and their interest increased but then disappeared altogether. For example, on average, there were three caricatures on international themes in each issue of Krokodil in 1922. But in 1927, more than half of the issues of the magazine did not have such caricatures. The same was the case with the magazine Begemot. It was only in the second half of 1927 when caricatures on international themes appeared due to the aggravation of Anglo-Soviet relations. Golubev believes that, on the one hand, such fluctuations were due to the internal situation and, on the other, they were due to the assessment of international events by the Soviet political leadership (Golubev 2018: 91).

Most of the caricatures were devoted to domestic life. Such phenomena as drunkenness and patronage, philistinism and bureaucracy, adherence to old everyday habits, etc. were subjected to ridicule. In 1927, there were special issues of the magazine Krokodil devoted to a single internal problem. For example, the third issue was devoted to bureaucracy, the thirteenth - to sloppiness, the twenty-eighth - to housewives and the status of a woman in the USSR, and the thirty-sixth issue was devoted to the problems of art in the Soviet country. The caricatures were consistent with the general theme of the issue.

In fact, any topic had a political connotation. This was due to both the ideology of the Bolsheviks and to the ideas of the intellectuals and other social groups about the society of the future. In mass consciousness, it was a perfect society, unlike those which existed before. The idea of constructive endeavour with participation of all social groups (except for the exploiters) came to the fore. Participation in the construction of a new life, from the point of view of revolutionary romantics, was supposed to contribute to the disclosure of talents and capabilities of the individual. Therefore, all the shortcomings were ridiculed in the Soviet satirical caricature. The secluded quiet life of an individual or a family seemed wrong in those years since there was no movement and development therein.

However, there were not only satirical caricatures but also humorous and friendly ones of the members of the government and the Central Committee of the Party, including those of Vladimir Lenin and Joseph Stalin. In the 1920s, there was no rigid ban on the depiction of leaders.

In 1927, the internal party struggle was vividly reflected in the caricature, Leon Trotsky being the object of ridicule. He turned from a hero, who was devoted friendly caricatures in the early 1920s, into a renegade deviated from the straight line of the party. This is how the image of this politician was presented by caricaturists. For example, there was the following caption under the caricature by Mel'nikov:

"What is the position of Comrade Trotsky now?!"

"Social? ... Sure, he is a lonely leader".

(Krokodil 1927. 43: 8)

The caption under the caricature by Cheremnykh was as follows: "Lenin died, but his work lives on! Trotsky is alive, but his cause is dead!" (Krokodil 1927. 45: 1).

Thus, the caricature occupied a large place in the daily life of the Soviet society. It was both popular and stimulated the artistic creativity of the masses, and contributed to the development of a humorous and satirical view of modern reality.

At the same time, the caricature was part of the Soviet propaganda apparatus. Therefore, it reflected the position of the party. Under its influence, the outlook of the Soviet people was formed. There is no doubt that vivid images created by talented artists were firmly imprinted in the minds of their contemporaries. 


\subsection{The agitprop theatre Sinyaya Bluza}

Agitprop theatres were another form of satire at the official level. They appeared during the Civil war and grew up after its end. Sinyaya Bluza was one of the most influential agitprop theatres. Its performances took place on every stage: at workers' village clubs, in manufactory workshops, and various institutions. The members of Sinyaya Bluza performed even in beer houses (The Russian State Archive of Literature and Arts F.1822. I. 2. D. 82: 43) to substitute the old culture at all levels. The specific character of the venue required a specific form of presentation. That is why the use of laughter was reasonable and effective. The performances of Sinyaya Bluza in drinking and foodservice establishments were successful. According to Viktor Ardov, the heads of state or private establishments, and the proprietors of beer houses invited the artists of Sinyaya Bluza for performances (The Russian State Archive of Literature and Arts F.1822. I. 2. D. 82: 44). It is supposed that there was an economic concern. It is likely that the performances of Sinyaya Bluza should draw the attention of the public and that is why the number of visitors increased.

The repertory of agitprop theatres always contained satirical couplets, criticizing 'external and internal enemies'. The members of Sinyaya Bluza raised the same problems as the periodicals did, e.g., bribery, bureaucracy, clergy, NEPmen, old traditions, etc. The performances of the agitprop theatre included different genres: chastushkas, sketches, minor dramatic vaudevilles, feuilletons, stand-up, dance and musical turns, acrobatics, and pantomime. The performances were entertaining and spectacular, but they kept their appeal to political topics. Sinyaya Bluza replaced the reading of magazines and newspapers for a lot of people.

The founders of Sinyaya Bluza objectively determined the cultural level of people. Laughter overthrew the old culture, mocked the weaknesses of the society, and, at the same time, enlightened the public. With the help of humorous sketches and chastushkas, the artists reported on the situation in the country, international events, and politicians. Shalamov remembered that "Sinyaya Bluza served the present time: it criticized the speculators and grabbers like the newspapers did; and it entered into a dialogue with Chamberlain about international politics in the oratories" (Shalamov 2003: 31).

The popularity of Sinyaya Bluza was so high that agitprop theatres of its followers appeared everywhere and the collections of repertoire were edited. There were similar agitprop theatres in rural areas, too. For example, there is a documentary record about the existence of an agitprop theatre in the village of Poim in Belinsky district of the Penza region. Another agitprop theatre was formed at a cloth factory called Voyna Dvortsam (War on the Palaces) in Luninsky district of the Penza region. According to the reports, the agitprop was registered as a circle of 30 members (Cultural Construction in the Penza Region. 1917-1938. Documents and Materials 1986: 235).

Sinyaya Bluza gained its recognition abroad (The Russian State Archive of Literature and Arts F.1822. I. 2. D. 82: 44). The performers of Sinyaya Bluza went for tours abroad and presented the Soviet reality to the audience. The amateur artists succeeded to receive a positive response of foreign audience and Sinyaya Bluza got its adherents outside Soviet Russia.

However, by the end of the 1920s, the movement of Sinyaya Bluza had started to decline. At first, the authorities supported this movement and provided the best venues for performances. But by the end of the 1920s, the authorities had seen a threat in the ambitious and free-thinking performances of the young artists. By 1933, Sinyaya Bluza ceased to exist.

Thus, the agitprop theatres were a new form of humour and satire that had no analogues in the pre-revolutionary period. They demonstrated the revolutionary enthusiasm of young people and their desire to establish a new society. The boldness of the performances both contributed to the rise in popularity of Sinyaya Bluza and led its activities to the end. 


\section{Conclusion}

1. Humour and satire were an integral part of political propaganda in the Soviet society of the 1920s. For the first time in Russian history, the government used laughter extensively for the political purpose to accomplish its aims. Having taken into consideration cultural differences of social groups, the Soviet authorities supported the edition of humorous and satirical press dedicated to specific layers of the society. The central party and state apparatus did not hinder but promoted the edition of satirical publications in all regions of the country, setting the targets for them by the resolutions of the Party Congresses. Applying the class approach, the Bolsheviks determined the objects and style of ridicule.

The characteristic features of official laughter were acuity, rudeness at times, strongly pronounced ideological position, subjectiveness, and one-sidedness. Everything that did not coincide with the new ideology, the new system of values, and the new mode of life was satirized.

2. At the official level, humour and satire came in various forms. First of all, they were represented by the satirical print like feuilletons, parodies, epigrams, poetries, caricatures, and cartoons. These forms differed in their quality and level. Their greatest advantage over other forms of satire was their accessibility. Village reading rooms, supplied with newspapers and magazines, became widespread all over the country. The reading of periodicals became an integral part of daily life which meant the availability of satire for the readers from all layers of the society. Secondly, there were performances of the agitprop theatres, which took place at any venues. That was a novelty born of the Revolution and the Civil War. The satirical performances, created by the young enthusiasts, gained popularity among people. But by the end of the 1920s, their free-thinking performances started to represent a threat to the authorities and the government stopped supporting them.

3. Despite diversity of forms, the content of satirical publications was featured by the uniformity of topics and images, since they were set by the government. As a result, stereotypical images of external and internal enemies were formed and the worldview of the Soviet person was formed.

4. One can highlight pseudo-satire along with satire in the Soviet official culture of laughter. The authorities used pseudo-satirical forms for mocking traditional values being the base of any society. Anything that did not pursue the goal of serving the interests of the Revolution was mocked, e.g., a family, home comfort, religion, and entertainment.

Thus, humour and satire took quite a great place in the daily life of Soviet citizens. Caricatures, cartoons, agitprop theatres, and feuilletons were actively used by ordinary citizens in daily life. The Soviet government used laughter consciously to pursue its political aims, forming the new view of the world being the most important one. The image of the world was formed persistently with the help of humour and satire every day. Ordinary people understood the language of posters, cartoons, and political caricatures well. Due to the creation of stereotypical images, the ideas of caricatures were understandable even for illiterate or poorly educated persons.

At the same time, humour and satire helped to pay attention to the problems of the new society and to deal with real shortcomings. Moreover, humour and satire helped to create the new system of values and to demonstrate new models of behaviour in daily life. 


\section{References}

Cultural Construction in the Penza Region. 1917-1938. Documents and Materials (1986). Saratov: Volga Book Publishing House (Penza Branch).

Davies, C. (2014). 'Political ridicule and humour under socialism'. European Journal of Humour Research 2 (3), pp. 1-27. Retrieved April 2, 2020 from https://europeanjournalofhumour.org/index.php/ejhr/article/view/23.

Efimov, B. E. (2000). Ten Decades. Moscow: Vagrius. Retrieved April 5, 2020 from https://www.litmir.me/br/?b=182928\&p=7.

Golubev, A. V. (2008). 'Chamberlain, Hitler and others: enemy images in Soviet cartoons, 1922-1939'. Russia and the Contemporary World 1. Retrieved October 4, 2019 from https://cyberleninka.ru/article/n/chemberlen-gitler-i-drugie-obrazy-vragov-v-sovetskoykarikature-1922-1939-godov.

Golubev, A. V. (2018). 'Soviet political caricature of the 1920s-1930s'. Russian History 6. Retrieved April 2, 2020 from https://russian-history.ru/s086956870002292-2-1/?sl=ru.

Happiness of Literature. State and Writers. 1925-1938. Documents (1997). Babichenko, D. L. (ed.). Moscow: Russian Political Encyclopedia (ROSSPEN).

Khrenov, N. A. (2002). Culture in the Era of Social Chaos. Moscow: URSS Publishing Group.

Klekh, I. (2013). 'Satirikon and satirikonists'. Vestnik Evropy 36. Retrieved April 10, 2020 from https://magazines.gorky.media/vestnik/2013/36/satirikon-i-satirikonczy.html.

Krokodil (1922). 1 (13). Retrieved April 13, 2019 from https://cloud.mail.ru/public/47rf/L9EpCnDvu/\%D0\%9A\%D1\%80\%D0\%BE\%D0\%BA\% D0\%BE\%D0\%B4\%D0\%B8\%D0\%BB\%201922/\%D0\%9A\%D1\%80\%D0\%BE\%D0\%BA $\% \mathrm{D} 0 \% \mathrm{BE} \% \mathrm{D} 0 \% \mathrm{~B} 4 \% \mathrm{D} 0 \% \mathrm{~B} 8 \% \mathrm{D} 0 \% \mathrm{BB} \% 2 \mathrm{C} \% 201922 \% 20 \% 2 \mathrm{C} \% 20 \% \mathrm{E} 2 \% 84 \% 96 \% 200$ 1.pdf.

Krokodil (1922). 2 (14). Retrieved April 13, 2019 from https://cloud.mail.ru/public/47rf/L9EpCnDvu/\%D0\%9A\%D1\%80\%D0\%BE\%D0\%BA\% D0\%BE\%D0\%B4\%D0\%B8\%D0\%BB\%201922/\%D0\%9A\%D1\%80\%D0\%BE\%D0\%BA $\% \mathrm{D} 0 \% \mathrm{BE} \% \mathrm{D} 0 \% \mathrm{~B} 4 \% \mathrm{D} 0 \% \mathrm{~B} 8 \% \mathrm{D} 0 \% \mathrm{BB} \% 2 \mathrm{C} \% 201922 \% 20 \% 2 \mathrm{C} \% 20 \% \mathrm{E} 2 \% 84 \% 96 \% 200$ 2.pdf.

Krokodil (1922). 7. $\quad$ Retrieved October $10, \quad 2020$ from https://cloud.mail.ru/public/47rf/L9EpCnDvu/\%D0\%9A\%D1\%80\%D0\%BE\%D0\%BA\% D0\%BE\%D0\%B4\%D0\%B8\%D0\%BB\%201922/\%D0\%9A\%D1\%80\%D0\%BE\%D0\%BA $\% \mathrm{D} 0 \% \mathrm{BE} \% \mathrm{D} 0 \% \mathrm{~B} 4 \% \mathrm{D} 0 \% \mathrm{~B} 8 \% \mathrm{D} 0 \% \mathrm{BB} \% 2 \mathrm{C} \% 201922 \% 20 \% 2 \mathrm{C} \% 20 \% \mathrm{E} 2 \% 84 \% 96 \% 200$ 7.pdf.

Krokodil (1922). $18 \quad$ (30). $\quad$ Retrieved April 13, 2019 from https://cloud.mail.ru/public/47rf/L9EpCnDvu/\%D0\%9A\%D1\%80\%D0\%BE\%D0\%BA\% D0\%BE\%D0\%B4\%D0\%B8\%D0\%BB\%201922/\%D0\%9A\%D1\%80\%D0\%BE\%D0\%BA $\% \mathrm{D} 0 \% \mathrm{BE} \% \mathrm{D} 0 \% \mathrm{~B} 4 \% \mathrm{D} 0 \% \mathrm{~B} 8 \% \mathrm{D} 0 \% \mathrm{BB} \% 2 \mathrm{C} \% 201922 \% 20 \% 2 \mathrm{C} \% 20 \% \mathrm{E} 2 \% 84 \% 96 \% 201$ 8.pdf.

Krokodil (1923). 2 (32). Retrieved July 26, 2019 from https://cloud.mail.ru/public/47rf/L9EpCnDvu/\%D0\%9A\%D1\%80\%D0\%BE\%D0\%BA\% D0\%BE\%D0\%B4\%D0\%B8\%D0\%BB\%201923/\%D0\%9A\%D1\%80\%D0\%BE\%D0\%BA $\% \mathrm{D} 0 \% \mathrm{BE} \% \mathrm{D} 0 \% \mathrm{~B} 4 \% \mathrm{D} 0 \% \mathrm{~B} 8 \% \mathrm{D} 0 \% \mathrm{BB} \% 2 \mathrm{C} \% 201923 \% 20 \% 2 \mathrm{C} \% 20 \% \mathrm{E} 2 \% 84 \% 96 \% 200$ 2.pdf.

Krokodil (1923). 3 (33). Retrieved October 10, 2020 from https://cloud.mail.ru/public/47rf/L9EpCnDvu/\%D0\%9A\%D1\%80\%D0\%BE\%D0\%BA\% D0\%BE\%D0\%B4\%D0\%B8\%D0\%BB\%201923/\%D0\%9A\%D1\%80\%D0\%BE\%D0\%BA $\% \mathrm{D} 0 \% \mathrm{BE} \% \mathrm{D} 0 \% \mathrm{~B} 4 \% \mathrm{D} 0 \% \mathrm{~B} 8 \% \mathrm{D} 0 \% \mathrm{BB} \% 2 \mathrm{C} \% 201923 \% 20 \% 2 \mathrm{C} \% 20 \% \mathrm{E} 2 \% 84 \% 96 \% 200$ 3.pdf. 
Krokodil (1923). $10 \quad$ (40). $\quad$ Retrieved April 13, 2019 from https://cloud.mail.ru/public/47rf/L9EpCnDvu/\%D0\%9A\%D1\%80\%D0\%BE\%D0\%BA\% D0\%BE\%D0\%B4\%D0\%B8\%D0\%BB\%201923/\%D0\%9A\%D1\%80\%D0\%BE\%D0\%BA \%D0\%BE\%D0\%B4\%D0\%B8\%D0\%BB\%2C\%201923\%20\%2C\%20\%E2\%84\%96\%201 $0 . p d f$.

Krokodil

(1927).

8. $\quad$ Retrieved October

10

2020 from https://cloud.mail.ru/public/47rf/L9EpCnDvu/\%D0\%9A\%D1\%80\%D0\%BE\%D0\%BA\% D0\%BE\%D0\%B4\%D0\%B8\%D0\%BB\%201927/\%D0\%9A\%D1\%80\%D0\%BE\%D0\%BA $\% \mathrm{D} 0 \% \mathrm{BE} \% \mathrm{D} 0 \% \mathrm{~B} 4 \% \mathrm{D} 0 \% \mathrm{~B} 8 \% \mathrm{D} 0 \% \mathrm{BB} \% 2 \mathrm{C} \% 201927 \% 20 \% 2 \mathrm{C} \% 20 \% \mathrm{E} 2 \% 84 \% 96 \% 200$ 8.pdf.

Krokodil

10. Retrieved

October

10

2020 from https://cloud.mail.ru/public/47rf/L9EpCnDvu/\%D0\%9A\%D1\%80\%D0\%BE\%D0\%BA\% D0\%BE\%D0\%B4\%D0\%B8\%D0\%BB\%201927/\%D0\%9A\%D1\%80\%D0\%BE\%D0\%BA \%D0\%BE\%D0\%B4\%D0\%B8\%D0\%BB\%2C\%201927\%20\%2C\%20\%E2\%84\%96\%201 0. pdf.

Krokodil

(1927).

43.

Retrieved

October

10, $\quad 2020$

from https://cloud.mail.ru/public/47rf/L9EpCnDvu/\%D0\%9A\%D1\%80\%D0\%BE\%D0\%BA\% D0\%BE\%D0\%B4\%D0\%B8\%D0\%BB\%201927/\%D0\%9A\%D1\%80\%D0\%BE\%D0\%BA $\% \mathrm{D} 0 \% \mathrm{BE} \% \mathrm{D} 0 \% \mathrm{~B} 4 \% \mathrm{D} 0 \% \mathrm{~B} 8 \% \mathrm{D} 0 \% \mathrm{BB} \% 2 \mathrm{C} \% 201927 \% 20 \% 2 \mathrm{C} \% 20 \% \mathrm{E} 2 \% 84 \% 96 \% 204$ 3.pdf.

Krokodil

45. Retrieved

October

10 2020 from https://cloud.mail.ru/public/47rf/L9EpCnDvu/\%D0\%9A\%D1\%80\%D0\%BE\%D0\%BA\% D0\%BE\%D0\%B4\%D0\%B8\%D0\%BB\%201927/\%D0\%9A\%D1\%80\%D0\%BE\%D0\%BA \%D0\%BE\%D0\%B4\%D0\%B8\%D0\%BB\%2C\%201927\%20\%2C\%20\%E2\%84\%96\%204 5.pdf.

Krotkov, A. (2015). Caricature. Uninvented Story. Moscow: AST Publishing House.

Lebina, N. B. (2015). Soviet Everyday Life: Norms and Anomalies. From War Communism to Great Style. Moscow: New Literary Observer Publishing House.

Gak, A. M. \& Glagoleva, A. M. (eds.) (1965). Lunacharsky A. V. about Cinema. Articles. Remarks. Scripts. Documents. Moscow: Iskusstvo.

Orlov, I. B. (2010). Soviet Everyday Life: Historical and Sociological Aspects of Formation. Moscow: HSE Publishing House.

Pod Znamenem Leninizma (1926). 26. Retrieved April 5, 2019 from http://dl.liblermont.ru/DL/Leninizm/L1926_n26.pdf.

Pyanov, A. S. (2007). 'Laughter and tears of Krokodil', in Krokodil of All Times and Peoples. Anthology of Humour and Satire from Russia in the 20th Century Vol. 49. Moscow: EKSMO.

Shalamov, V. T. (2003). Memorials. Moscow: AST Publishing House: Astrel Publishing House: ASTOL.

Stolyar, M. (2011). The Soviet Laughter Culture. Kiev: Stylos.

Stykalin, S. I. \& Kremenskaya, I. K. (1963). Soviet Satirical Press of 1917-1963. Retrieved October 11, 2019 from https://coollib.com/b/188906/read.

Terra-Lexicon: Illustrated Encyclopedic Dictionary (1998). Moscow: TERRA.

The Communist Party of the Soviet Union in Resolutions and Decisions of Congresses, Conferences and Plenums of the Central Committee (1898-1988) (1983). Egorov, A. G. \& Bogolyubov, K. M. (eds.). Vol. 2. 1917-1922. Moscow: Institute of Marxism-Leninism under the Central Committee of the CPSU. Retrieved October 10, 2019 from http://elib.shpl.ru/ru/nodes/8624-t-2-1917-1922-1983.

The Russian State Archive of Literature and Arts F.1822. I. 2. D. 82. 'Ardov Viktor Efimovich. Four decades ago. About Sinyaya Bluza'. 


\begin{tabular}{|c|c|c|c|c|c|c|c|}
\hline Tovarishch & (1922) & 1. & Retrieved & April & 8 & 2019 & from \\
\hline \multicolumn{8}{|c|}{ http://dl.liblermont.ru/DL/November_16/Tovarich_1922_v1.pdf. } \\
\hline $\begin{array}{r}\text { Tovarishch } \\
\text { http://d }\end{array}$ & $\begin{array}{l}\text { (1923). } \\
\text { rmont.ru }\end{array}$ & $\begin{array}{l}4 . \\
\mathrm{Cor}\end{array}$ & $\begin{array}{l}\text { Retrieved } \\
\text { C1923_n4.p }\end{array}$ & April & 8 , & 2019 & from \\
\hline Tovarishch & (1923). & 13 & Retrieved & April & 8 , & 2019 & rom \\
\hline
\end{tabular}

